\title{
Pembentukan Karakter Siswa melalui Penerapan Disiplin Tata Tertib Sekolah
}

\author{
Suradi $^{1}$ \\ ${ }^{1}$ SMPN 3 Tulungagung \\ Email: ${ }^{1}$ suradi789@gmail.com
}

\section{Tersedia Online di \\ http://www.jurnal.unublitar.ac.id/ index.php/briliant}

\begin{tabular}{l}
\hline Sejarah Artikel \\
\hline Diterima pada 20 Oktober 2017 \\
Disetuji pada 13 November 2017 \\
Dipublikasikan pada 13 \\
November 2017 Hal. $522-533$ \\
\hline
\end{tabular}

\section{Kata Kunci:}

pembentukan karakter, siswa smp, disiplin sekolah,

\section{DOI:}

http://dx.doi.org/10.28926/briliant .$v 2 \mathrm{i} 4.104$

\begin{abstract}
Abstrak: Karakter sangat dibutuhkan untuk mencapai keberhasilan belajar siswa. Individu yang berkarakter baik adalah individu yang bias membuat keputusan dan siap untuk mempertanggungjawabkan setiap akibat dari keputusan yang telah dibuat. Siswa Sekolah Menengah Pertama adalah siswa siswi yang berusia sekitar 12 sampai dengan usia 16 tahun, merupakan anak yang memasuki transisi perubahan masa anak anak menuju masa remaja awal yang mana biasanya mereka ingin menunjukan jati dirinya dengan berperilaku mengimitasi idola-idolanya. Cara pembentukan karakter yang baik bagi para siswa agar kelak bisa menjadi warga masyarakat yang berkepribaian baik, yang bersikap dan perilaku religious, toleran, jujur, disiplin, kerja keras, kreatif, tanggung jawab, mandiri, demokratis, menghargai karya orang lain dan cinta damai adalah melalui penerapan disiplin tata tertib sekolah.
\end{abstract}

Undang-undang Nomor 20 Tahun 2003 tentang Sistem Pendidikan Nasional mengamanatkan kompetensi lulusan yang menyangkut pengetahuan, keterampilan, dan sikap yang dirumuskan berdasarkan kebutuhan pada tingkat individu, masyarakat, bangsa dan negara, serta peradaban tuntutan globalisasi yang menuntut agar semua mata pelajaran harus berkontribusi terhadap pembentukan sikap, keterampilan, dan pengetahuan dan konteks pemahaman akan jauh lebih baik dimengerti melalui pendekatan pengetahuan multi disiplin. Sekolah merupakan lembaga pendidikan yang diciptakan oleh masyarakat untuk menyediakan lingkungan belajar dan ruang belajar untuk belajar dan mengajar serta tempat menerima dan memberi pelajaran.

Kegiatan pembelajaran diselenggarakan untuk membentuk watak, membangun pengetahuan, sikap dan kebiasaan-kebiasaan untuk meningkatkan mutu kehidupan peserta didik. Atas dasar itulah pentingnya kegiatan pembelajaran yang memberdayakan semua potensi peserta didik untuk menguasai kompetensi yang diharapkan. Pemberdayaan diarahkan untuk mendorong pencapaian kompetensi dan perilaku khusus supaya setiap individu mampu menjadi pembelajar sepanjang hayat dan mewujudkan masyarakat belajar. Kegiatan belajar mengajar atau pembelajaran adalah proses penyampaian pengetahuan atau latihan kecerdasan, berbagai kecakapan untuk masa depan siswanya dalam terjun dimasyarakat kelak. Pada dasarnya sekolah harus mampu memenuhi kebutuhan masyarakat dibidang pembelajaran yang berorientasi pada pembentukan sikap, 
menyampaikan kebutuhan pengetahuan dan ketrampilan masa kini untuk memberikan bekal kepada anak didik dalam mencapai kehidupan lebih baik dimasa mendatang. Dari masa kini dan seturusnya kebutuhan masyarakat akan pembelajaran tentu saja makin banyak dan semakin kompleks, mereka tidak hanya membutuhkan pengetahuan yag teoritis semata tetapi sangat memerlukan pengetahuan pada aspeks praktis yang berupa kecakapan atau ketrampilan yang lebih kompetitif.

Dengan pesatnya kemajuan pengetahuan sosial dan teknologi baik internasional maupun lokal tantangan komunikasi antar bangsa yang menglobalisasi adalah keniscayaan. Kita sebagai warga dunia global tentu saja tidak mungkin untuk menghidari tantangan yang berada didepan mata kita. Laju perkembangan komunikasi transformasi yang sangat tinggi menyebabkan pergaulan tidak dapat lagi dibatasi oleh batas-batas negara. Pengaruhnya terhadap perubahan tatanan kehidupan masyarakat sosial pasti akan menjadi tantangan yang nyata. Pergeseran pola hidup dan perilaku warga akan banyak dipengaruhi oleh budaya asing yang menurut mereka merupakan budaya kekinian. Kebudayaan bangsa yang mengandung nilai adap budaya positif, baik terancam pudar. Sekolah sebagai lembaga formal pusat pengembangan pengetahuan, tehnologi dan budaya bangsa yang berkarakter baik, beradap, dan beretika harus bersiap diri dalam membentengi anak didiknya dari pengaruh variatif, yang berpengaruh pada perilaku masyarakat yang mengarah akan mengganggu stabilitas bangsa, perilaku dan pola kehidupan kondusif positif kearah pola pikir dan perilaku negative. Pendidikan Indonesia bertujuan untuk mengembangkan potensi peserta didik agar menjadi manusia yang (1) beriman dan bertaqwa kepada Tuhan Yang maha Esa, (2) berakhlak mulia, (3) sehat, (4) berilmu, (5) cakap, (6) kreatif, (7) mandiri, (8) menjadi warga negara yang demokratis, dan (9) bertanggung jawab (UU No. 20 tahun 2003 tentang Sistem Pendidikan Nasional).

Untuk mencapai tujuan nasional tersebut semua stake holder sekolah harus bersiap diri dengan mengantisipasi hal hal yang tidak diinginkan dari pengaruh komunikasi global terhadap pola pikir dan perilaku siswa, salah satu caranya adalah menanamkan karakter/ pembiasaan budaya disiplin terhadap para peserta didik untuk melaksanakan tata tertib sekolahnya. Upaya ini perlu dilakukan secara terus menerus bagi siswa sekolah menengah pertama untuk meningkatkan karakter baiknya yang di peroleh di sekolah dasar dalam rangka membentuk warga negara yang berkarakter lebih baik dan competence lebih tinggi dan tangguh kemampuannya untuk berpartisipasi dalam pergaulan dunia yang tetap mengutamakan kemaslahatan bangsa. Upaya membentukan karakter peserta didik di tingkat sekolah menengah pertama melalui penerapan disiplin dalam melaksanakan tata tertib sekolah ini merupakan periode tepat untuk menanamkan karakter positif pada diri siswa dimana hal inilah yang akan menjadi blue print yang tidak akan terlupakan sepanjang hidupnya. Selain itu karakter baik adalah salah satu sikap fundamental pola pikir dan perilaku seseorang untuk mencapai keberhasilan hidup yang lebih baik. Maka sudah selayaknya sekolah mempersiapkan peserta didiknya berkarakter lebih baik yang menjujung tinggi budaya dan etika sebagai bekal hidup di masa depannya. Selanjutnya tulisan ini akan membahas tentang pengertian karakter, pembentukan karakter, disiplin dan tata tertip sekolah. 


\section{PEMBAHASAN}

\section{Pengertian Karakter}

Karakter adalah cara berpikir dan berperilaku yang menjadi ciri khas tiap individu untuk hidup dan bekerjasama, baik dalam lingkup keluarga, masyarakat, bangsa dan negara. Individu yang berkarakter adalah individu yang bisa membuat keputusan dan siap mempertanggungjawabkan tiap akibat dari keputusan yang ia buat. Jika dikaitkan dengan dunia pendidikan, karakter siswa yang baik adalah karakter siswa yang menunjukkan bahwa dirinya seorang pelajar yang berpendidikan. Anak yang terpelajar dan terdidik melalui proses pembelajaran dan pendidikan yang baik tentu saja akan menghasilkan anak yang berkarakter baik. Mereka akan mempunyai watak yang jujur, disiplin, bertanggung jawab, sopan santun, peduli terhadap orang lain, tidak sombong, mampu menghargai karya orang lain, memiliki daya kreatif tinggi. Kita atau siapapun orang lain akan bisa membedakan karakter seseorang orang yang terdidik dan tidak terdidik dari pola pikir dan perilakunya, tata tutur pembicaraannya, tindak tanduknya, tata rias/pakaiannya dan lain lain.

Menurut Kamus Besar Bahasa Indonesia (2016), karakter memiliki arti Sifat-sifat kejiwaan, akhlak atau budi pekerti yang membedakan seseorang dari yang lain. Karakter adalah kumpulan fitur dan sifat yang membentuk batin individu yang mempengaruhi segenap pikiran, perilaku, budi pekerti, tabiat yang dimiliki manusia atau makluk hidup lainnya. Sifat individu dari ciri atau sifat seperti itu mengacu pada perilaku atau kualitas kepribadian/sikap seseorang/ beberapa orang. Suyanto mengemukakan karakter adalah cara berpikir dan berperilaku yang menjadi ciri khas tiap individu untuk hidup dan bekerjasama. Dari definisi di atas telah jelas bahwa penekanan karakter itu adalah pada cara berpikir dan berperilaku.

Menurut sumber dari Balitbang, Kementerian Pendidikan Nasional, bahwa ruang lingkup nilai moral dalam rangka pembentukan karakter yang harus dikembangkan di lingkungan keluarga adalah sebagai berikut (1) Religius: Sikap dan perilaku yang patuh dalam melaksanakan ajaran agamadianutnya, toleran terhadap pelaksanaan ibadah agama lain, dan hidup rukun dengan pemeluk agama lain; (2) Jujur: Perilaku yang didasarkan pada upaya menjadikan dirinya sebagai orangselalu dapat dipercaya dalam perkataan, tindakan, dan pekerjaan; (3) Toleransi: Sikap dan tindakan yang menghargai perbedaan agama, suku, etnis, pendapat, sikap, dan tindakan orang lain yang berbeda dari dirinya; (4) Disiplin: Tindakan yang menunjukkan perilaku tertib dan patuh pada berbagai ketentuan dan peraturan; (5) Kerja Keras: Perilaku yang menunjukkan upaya sungguhsungguh dalam mengatasi berbagai hambatan belajar dan tugas, serta menyelesaikan tugas dengan sebaik-baiknya; (6) Kreatif: Berpikir dan melakukan sesuatu untuk menghasilkan cara atau hasil baru dari sesuatu yang telah dimiliki; (7) Mandiri: Sikap dan perilaku yang tidak mudah tergantung pada orang lain dalam menyelesaikan tugas-tugasnya; (8) Demokratis: Cara berfikir, bersikap, dan bertindak yang menilai sama Hak dan kewajiban dirinya dan orang lain; (9) Rasa Ingin Tahu: Sikap dan tindakan yang selalu berupaya untuk mengetahui lebih mendalam dan meluas dari sesuatuyang dipelajarinya, dilihat, dan didengar; (10) Semangat Kebangsaan: Cara berpikir, bertindak, dan berwawasan yang menempatkan kepentingan bangsa dan negara di atas kepentingan diri dan kelompoknya; (11) Cinta Tanah Air: Cara berfikir, bersikap, dan berbuat yang 
menunjukkankesetiaan, kepedulian, dan penghargaan yang tinggi terhadap bahasa, lingkungan fisik, sosial, budaya, ekonomi, dan politik bangsa; (12) Menghargai Prestasi: Sikap dan tindakan yang mendorong dirinya untuk menghasilkan sesuatu yang berguna bagi masyarakat, dan mengakui, serta menghormati keberhasilan orang lain; (13) Bersahabat/Komuniktif: Tindakan yang memperlihatkan rasa senang berbicara, bergaul, dan bekerja sama dengan orang lain; (14) Cinta Damai: Sikap, perkataan, dan tindakan yang menyebabkan orang lain merasa senang dan aman atas kehadiran dirinya; (15) Gemar Membaca: Kebiasaan menyediakan waktu untuk membaca berbagai bacaan yang memberikan kebajikan bagi dirinya; (16) Peduli Lingkungan: Sikap dan tindakan yang selalu berupaya mencegah kerusakan pada lingkungan alam di sekitarnya, dan mengembangkan upaya-upaya untuk memperbaiki kerusakan alam yang sudah terjadi.

Menurut Megawangi (2004), anak-anak akan tumbuh menjadi pribadi yang berkarakter apabila dapat tumbuh pada lingkungan yang berkarakter, sehingga fitrah setiap anak yang dilahirkan suci dapat berkembang segara optimal. Mengingat lingkungan anak bukan saja lingkungan keluarga yang sifatnya mikro, maka semua pihak - keluarga, sekolah, media massa, komunitas bisnis, dan sebagainya - turut andil dalam perkembangan karakter anak. Dengan kata lain, mengembangkan generasi penerus bangsa yang berkarakter baik adalah tanggung jawab semua pihak. Tentu saja hal ini tidak mudah, oleh karena itu diperlukan kesadaran dari semua pihak bahwa pendidikan karakter merupakan"PR" yang sangat penting untuk dilakukan segera. Terlebih melihat kondisi karakter bangsa saat ini yang memprihatinkan serta kenyataan bahwa manusia tidak secara alamiah (spontan) tumbuh menjadi manusia yang berkarakter baik, sebab menurut Aristoteles (dalam Megawangi, 2004), hal itu merupakan hasil dari usaha seumur hidup individu dan masyarakat.

\section{Sekolah Menengah Pertama (SMP)}

Sekolah adalah sebuah lembaga pendidikan bagi siswa sampai usia 19 tahun. Kata sekolah berasal dari Bahasa Latin: skhole, scola, scolae atau skhola yang memiliki arti: waktu luang atau waktu senggang, di mana ketika itu sekolah adalah kegiatan di waktu luang bagi anak-anak di tengah-tengah kegiatan utama mereka, yaitu bermain dan menghabiskan waktu untuk menikmati masa anakanak dan remaja. Kegiatan dalam waktu luang itu adalah mempelajari cara berhitung, cara membaca huruf dan mengenal tentang moral (budi pekerti) dan estetika (seni). Untuk mendampingi dalam kegiatan scola anak-anak didampingi oleh orang ahli dan mengerti tentang psikologi anak, sehingga memberikan kesempatan yang sebesar-besarnya kepada anak untuk menciptakan sendiri dunianya melalui berbagai pelajaran di atas.

Kurikulum 2013 menjelaskan sekolah merupakan bagian dari masyarakat yang memberikan pengalaman belajar terencana dimana peserta didik menerapkan apa yang dipelajari di sekolah ke masyarakat dan memanfaatkan masyarakat sebagai sumber belajar;

Sekolah Menengah Pertama (disingkat SMP) adalah jenjang pendidikan dasar pada pendidikan formal di Indonesia setelah lulus dari Sekolah Dasar (SD atau sederajat). Sekolah menengah pertama ditempuh dalam kurun waktu 3 tahun (kelas 7 sampai kelas 9). Dulunya sekolah menengah pertama ini pernah disebut 
sebagai Sekolah Lanjutan Tingkat Pertama (SLTP), hingga pada tahun ajaran 2003-2004 SLTP diganti dengan sebutan Sekolah Menengah Pertama (SMP).

Beberapa kategori serupa / setahap dengan Sekolah Menengah Pertama (SMP atau sederajat) diantaranya: Madrasah Tsanawiyah (MTs) dan Kelompok Belajar/ Program Paket B

Sekolah menengah yang diselenggarakan oleh pemerintah maupun swasta. Sejak pelaksanaan otonomi daerah pada tahun 2001, pengelolaan sekolah menengah pertama di Indonesia yang sebelumnya berada di bawah Departemen Pendidikan, kini menjadi tanggung jawab daerah pemerintah kabupaten / kota. Sedangkan Departemen Pendidikan hanya bertindak sebagai regulator dalam bidang standar nasional pendidikan. Secara struktural, sekolah menengah pertama adalah unit teknis pelayanan pendidikan kabupaten/ kota.

Di Indonesia mulai diberlakukan program wajib belajar 9 tahun yaitu antara usia 7-15 tahun, ini artinya setiap warga negara Indonesia wajib mendapatkan pendidikan mulai dari Sekolah Dasar (SD atau sederajat) sampai Sekolah Menengah Pertama (SMP atau sederajat). Para siswa yang telah berhasil atau dinyatakan Lulus pada tingkat ini bisa melanjutka ketahap pendidikan diatasnya, yaitu diantaranya sebagai berikut: Sekolah Menengah Atas/ Kejuruan, Madrasah Aliyah / Kejuruan, dan Kelompok Belajar / Program Paket C.

\section{Tata Tertib Sekolah}

Sebelum membahas tentang tujuan tata tertib yang lebih luas, akan penulis uraikan terlebih dahulu tujuan dari peraturan. Menurut Hurlock (1990: 85), yaitu: peraturan bertujuan untuk membekali anak dengan pedoman berperilaku yang disetujui dalam situasi tertentu. Misalnya dalam peraturan sekolah, peraturan ini memuat apa yang harus dilakukan dan apa yang tidak boleh dilakukan oleh siswa, sewaktu berada di lingkungan sekolah. Tujuan tata tertib adalah untuk menciptakan suatu kondisi yang menunjang terhadap kelancaran, ketertiban dan suasana yang damai dalam pembelajaran. Dalam informasi tentang Wawasan Wiyatamandala (1993: 21) disebutkan bahwa ketertiban adalah suatu kondisi dinamis yang menimbulkan keserasian dan keseimbangan tata kehidupan bersama sebagai makhluk Tuhan Yang Maha Esa.

Sekolah sebagai lembaga pendidikan yang memiliki tujuan membentuk manusia yang berkualitas, tentunya sangat diperlukan suatu aturan guna mewujudkan tujuan tersebut. Lingkungan sekolah khususnya tingkat SMP yang berangotakan remaja-remaja awal yang sedang dalam masa transisi, sangat rentan sekali terhadap perilaku yang menyimpang. Oleh karena itu diperlukan suatu hukum atau aturan yang harus diterapkan di sekolah yang bertujuan untuk membatasi setiap perilaku siswa. Di lingkungan sekolah yang menjadi "hukum" nya adalah tata tertib sekolah. Departemen Pendidikan dan Kebudayaan (1998: 37), mengemukkan bahwa peraturan tata tertib sekolah adalah peraturan yang mengatur segenap tingkah laku para siswa selama mereka bersekolah untuk menciptakan suasana yang mendukung pendidikan.

Dalam kondisi sehari-hari, kondisi di atas mencerminkan keteraturan dalam pergaulan, penggunaan dan pemeliharaan sarana dan prasarana dan dalam mengatur hubungan dengan masyarakat serta lingkungan. Menurut Kusmiati (2004: 22), bahwa tujuan diadakannya tata tertib salah satunya sesuai dengan yang tercantum dalam setiap butir tujuan tata tertib 
Menurut Depdikbud (1989) pengertian tata tertib sekolah adalah aturan atau peraturan yang baik dan merupakan hasil pelaksanaan yang konsisten (tatap azas) dari peraturan yang ada. Menurut Mulyono (2000) tata tertib adalah kumpulan aturan-aturan yang dibuat secara tertulis dan mengikat anggota masyarakat. Aturan-aturan ketertiban dalam keteraturan terhadap tata tertib sekolah, meliputi kewajiban, keharusan dan larangan-larangan.

Tata tertib sekolah merupakan patokan atau standar untuk hal-hal tertentu. Sesuai dengan keputusan Direktur Jenderal Pendidikan Dasar dan Menengah Nomor 158/C/Kep/T.81 Tanggal 24 September 1981. Ketertiban berarti kondisi dinamis yang menimbulkan keserasian, keselarasan dan keseimbangan dalam tata hidup bersama makhluk Tuhan Yang Maha Esa. Ketertiban sekolah tersebut dituangkan dalam sebuah tata tertib sekolah.

Tim Dosen Jurusan Administrasi Pendidikan FIP IKIP Malang (1989) mengartikan tata tertib sekolah: sebagai kesediaan mematuhi ketentuan berupa peraturan-peraturan tentang kehidupan sekolah sehari-hari. Tata tertib sekolah disusun secara operasional guna mengatur tingkah laku dan sikap hidup siswa, guru dan karyawan administrasi.

Secara umum tata tertib sekolah dapat diartikan sebagai ikatan atau aturan yang harus dipatuhi setiap warga sekolah tempat berlangsungnya proses belajar mengajar. Pelaksanaan tata tertib sekolah akan dapat berjalan dengan baik jika Guru, aparat sekolah dan siswa telah saling mendukung terhadap tata tertib sekolah itu sendiri, kurangnya dukungan dari siswa akan mengakibatkan kurang berartinya tata tertib sekolah yang diterapkan di sekolah.

Peraturan sekolah yang berupa tata tertib sekolah merupakan kumpulan aturan-aturan yang dibuat secara tertulis dan mengikat di lingkungan sekolah. Dari pengertian di atas dapat dipahami bahwa tata tertib sekolah merupakan satu kesatuan yang tidak dapat dipisahkan satu dengan yang lain sebagai aturan yang berlaku di sekolah agar proses pendidikan dapat berlangsung dengan efektif dan efisien.

Berdasarkan pandangan/keterangan tentang Tata Tertib/Disiplin Sekolah diatas bisa disimpulkan bahwa tata tertib sekolah disusun secara operasional guna mengatur tingkah laku dan sikap hidup siswa, guru dan karyawan administrasi disekolah yang bersangkutan. Pelaksanaan tata tertib sekolah yang merupakan sarana untuk meningkatkan disiplin belajar siswa akan dapat berjalan dengan baik jika Guru, aparat sekolah dan siswa telah saling mendukung terhadap tata tertib sekolah itu sendiri, kurangnya dukungan dari siswa dan seluruh stake holder sekolah akan mengakibatkan kurang berartinya tata tertib sekolah yang diterapkan di sekolah itu juga.

Mengutip contoh Tata Tertib Sekolah yang diterapkan untuk mengatur tingkah laku dan sikap hidup siswa, guru dan karyawan administrasi di SMP Negeri Tulungagung meliputi hal-hal sebagai berikut: (1) Masuk Sekolah: Semua Siswa harus hadir disekolah selambat-lambatnya 10 menit sebelum pelajaran dimulai, Siswa yang terlambat datang tidak diperkenanakan masuk kelas sebelum lapor ke guru piket/guruBK, Siswa absen sungguh-sungguh sakit atau keperluan sangat penting, Siswa yang absen harus mengirim surat ijin dan apabila sakit lebih dari tiga hari harus mengirim surat keterangan dokter. Siswa yang telah diperingatkan dan mendapat sanksi masih sering absen tanpa keterangan akan dikembalikan ke orang tua (dikeluarkan). (2) Kewajiban Siswa: Taat kepada Guru 
dan Kepala Sekolah, Taat terhadap tata tertib yang ditentukan ole sekolah, Ikut bertanggung jawab terhadap pelaksanaan $7 \mathrm{~K}$, Ikut menjaga nama baik sekolah, baik didalam maupun diluar sekolah, Menghormati guru dan saling menghargai sesama siswa, Siswa tidak menaiki sepeda di halaman sekolah, Siswa yang membawa kendaraaan sepeda agar menempatkan ditempat yang telah ditentukan dalam keadan terkunci, Ikut membantu agar tata tertib dapat ditaati. (3) Larangan Siswa: Meninggalkan sekolah selama pelajaran berlangsung tanpa seizing dari guru piket/guru BK, Membawa sepeda motor ke sekolah, Membeli makanan dan minuman di luar sekolah, Memakai perhiasan yang beerlebihan serta berdandan yang tidak sesuai dengan pelajar, Merokok didalam dan diluar sekolah, Pinjam meminjam uang dan alaat pelajaran sesame siswa, Mengganggu jalannya pelajaran baik terhadap kelasnya maupun terhadap kelas lain, Berada atau bermain di tempat sepeda, Berada dalam kelas selama istirahat, Berkelahi dan main hakim sendiri jika menemui persoalan sesame siswa, Menjadi anggota perkumpulan anak-anak nakal dan geng terlarang, Memeras teman satu kelas, main kartu (judi) di sekolah, Menggunakan HP yang menggangu efektivitas waktu pembelajaran. (4) Hal Pakaian: Setiap siswa memakai seragam lengkap, Siswa putri dilarang alat kosmetika yang lazim dipakai orang dewasa dan memanjangkan kuku serta mengecatnya (kutek), Rambut dipotong rapi, bersih dan terpelihaara (tidak dicat), Pakaian olah raga harus memenuhi ketentuan sekolah. (5) Hak Siswa: Siswa berhak mengikuti pelajaran selama tidak melanggar tata teertib, Siswa berhak memilih/ mengikuti kegiatan ekstra kurikuler, Siswa berhak menggunakan fasilitas sekolah seperti perpustakaan, laboratorium IPA, aboratorium computer, laboratorium Bahasa dan saraana lain, Siswa mendapat perlakuan sama selama tidak melanggar tata tertib sekolah.

\section{Pengertian Kedisiplinan}

Disiplin adalah suatu kondisi yang tercipta dan terbentuk melalui proses dari serangkaian perilaku yang menunjukkan nilai-nilai ketaatan, kepatuhan, kesetiaan, keteraturan dan ketertiban. Disiplin akan membuat seseorang tahu dan dapat membedakan hal-hal apa yang seharusnya dilakukan, yang wajib dilakukan, yang boleh dilakukan, yang tak sepatutnya dilakukan (karena merupakan hal-hal yang dilarang). Bagi seorang yang berdisiplin, karena sudah menyatu dalam dirinya, maka sikap atau perbuatan yang dilakukan bukan lagi dirasakan sebagai beban, namun sebaliknya akan membebani dirinya apabila ia tidak berbuat disiplin. Nilai-nilai kepatuhan telah menjadi bagian dari perilaku dalam kehidupannya. Disiplin yang mantap pada hakikatnya akan tumbuh dan terpancar dari hasil kesadaran manusia. Sebaliknya, disiplin yang tidak bersumber dari kesadaran hati nurani akan menghasilkan disiplin yang lemah dan tidak akan bertahan lama, atau disiplin yang statis, tidak hidup (Djojonegoro dalam Soemarmo, 1998: 20-21).

Pengertian Disiplin Belajar Siswa, Disiplin apa bila dilihat dari segi bahasanya itu sendiri adalah latihan ingatan dan watak untuk menciptakan pengawaasan (kontrol diri) atau bisa juga kebiasaan mematuhi ketentuan dan perintah. Jadi arti Pengertian Disiplin secara lengkap adalah kesadaran untuk melakukan sesuatu pekerjaan dengan tertip dan sesuai dengan peraaturanpaeraturan yang berlaku dengan penuh tanggung jawab tanpa paksaan dari siapapun. (Mas'udi, 2000:88). Suratman memberikan pengertian disiplin sebagai 
suatu ketaatan yang sungguh-sungguh dan didukung oleh kesadaran untuk menunaikan tugas dan kewajiban serta sikap dan perilaku sesuai dengan aturan atau tata kelakuan yang semestinya di dalam suatu lingkungan tertentu (Suratman, 1999: 32).

Kedisiplinan adalah hal mentaati tata tertib di segala aspek kehidupan, baik agama, budaya, pergaulan, sekolah, dan lain-lain. Dengan kata lain, kedisiplinan merupakan kondisi yang tercipta dan terbentuk melalui proses dari serangkaian perilaku individu yang menunjukkan nilai-nilai ketaatan, kesetiaan, keteraturan dan ketertiban. Hal ini berdasarkan pada pengertian dalam Kamus besar Bahasa Indonesia, yang berasal dari kata disiplin berarti ketaatan atau kepatuhan kepada peraturan tata tertib dan sebagainya. Ki Hajar Dewantoro (1967: 453) menyebutkan bahwa disiplin tak lain adalah peraturan tata tertib yang dilakukan secara tegas dan ketat. Dari pengertian dasar tersebut, kemudian berlanjut dengan istilah kedisiplinan yang dapat diartikan sebagai keadaan yang taat kepada peraturan tata tertib.

Selaras dengan pengertian kedisiplinan tersebut, Suradisastra (1991: 29) pun menjelaskan bahwa: kedisiplinan berasal dari kata disiplin yang berarti sikap untuk menepati apa yang telah dijanjikan, apa yang telah direncanakan. Kemudian dijelaskan pula, bahwa: disiplin mengandung makna keteguhan hati, kekuatan jiwa, tidak mudah tergoda oleh hal-hal yang dapat mencelakakan dirinya. Keberhasilan dalam suatu usaha atau dalam mencapai cita-cita akan tergantung kepada dimiliki tidaknya sikap disiplin. Orang yang berdisiplin akan berperilaku apa yang seharusnya diperbuat, tidak mengada-ada, tidak dilebih- lebihkan tetapi juga tidak dikurangi dari keadaan yang sebenarnya. Diam tepat pada pijakannya, melangkah tepat gerakannya, melaju sesuai arahnya. Sikap disiplin dapat dilakukan untuk setiap perilaku, seperti disiplin dalam belajar, disiplin dalam bekerja, disiplin dalam beraktivitas lainnya seperti dalam hal olahraga.

Westra (1977: 96), mengemukakan pengertian kedisiplinan sebagai Suatu keadaan tertib dimana orang-orang yang tergabung di dalam organisasi tunduk pada peraturan-peraturan yang ada dengan rasa senang hati. Pendapat itu menunjukkan bahwa disiplin merupakan ketaatan dan kepatuhan pada peraturan yang dilakukan dengan rasa senang hati, bukan karena dipaksa atau terpaksa.

Sedangkan menurut Widodo DS (1984:57) bahwa, Kedisiplinan adalah kesetiaan dan ketaatan seseorang, norma-norma, instruksi-instruksi yang dinyatakan berlaku untuk orang atau orang tersebut. Dari pendapat tersebut terlihat jelas bahwa pengertian kedisiplinan mengandung beberapa unsur yakni ketaatan, pengetahuan, kesadaran, ketertiban dan perasaan senang di dalam menjalankan tugas dan mematuhi atau mentaati segala peraturan-peraturan perundangan yang dinyatakan berlaku.

\section{Manfaat Tata-Tertib}

Tata tertib sekolah mempunyai dua fungsi yang sangat penting dalam membantu membiasakan anak mengendalikan dan mengekang perilaku yang diinginkan, seperti yang dikemukakan oleh Hurlock (1990: 85), yaitu: (1) Peraturan mempunyai nilai pendidikan, sebab peraturan memperkenalkan pada anak perilaku yang disetujui oleh anggota kelompok tersebut. Misalnya anak belajar dari peraturan tentang memberi dan mendapat bantuan dalam tugas sekolahnya, bahwa menyerahkan tugasnya sendiri merupakan satu-satunya cara 
yang dapat diterima di sekolah untuk menilai prestasinya; (2) Peraturan membantu mengekang perilaku yang tidak diinginkan. Agar tata tertib dapat memenuhi kedua fungsi di atas, maka peraturan atau tata tertib itu harus dimengerti, diingat, dan diterima oleh individu atau siswa. Bila tata tertib diberikan dalam kata-kata yang tidak dapat dimengerti, maka tata tertib tidak berharga sebagai suatu pedoman perilaku.

Tata Tertib Sekolah yang biasanya hanya berbunyi/bertuliskan untuk disiplin para peserta didik namun begitu bagi guru dan semua stake holder sekolah sebagai garda terdepan terlaksannya tata tertib sekolah yang mengedepankan Penguatan Pendidikan Karakter demi terciptanya Adi Wiyata yang tertib,disiplin, efektif dan efisien dalam melaksanaan proses pembelajaran sudah selayaknya mereka sadar melaksanakan tanggung jawabnya sebagai contoh, motor, motivator, inisiatordan kolaborator dalam pembentukan karakter lebih baik bagi peserta didik yang menjujung tinggi adab, budaya dan etika sebagai bekal hidup bermasyarakat, berbangsa dan bernegara di masa depannya. Untuk mendukung dalam mensuksekan terlakasannya operasional Tata Tertib Sekolah yang hanya focus kepada kedisiplinan/ketertiban siswa tersebut stakeholder sekolah perlu merumuskan program pendukung yang merupakan tata tertib bagi bagi guru, kepala sekolah maupun tata usaha sebagai landasan tata aturan yang mengikat bagi mereka dalam melaksananan tugas dan kewajibannya di sekolah.

Karena tata tertib sekolah berisikan keharusan yang harus dilaksanakan oleh siswa dan larangan yang harus tidak dilakukan oleh siswa yang juga berfungsi sebagai pengendali bagi perilaku/ perbuatan siswa, dan juga mengandung sanksi bagi siswa yang melanggarnya, maka kesimpulan yang dapat penulis kemukakan yaitu bahwa tata tertib sekolah berfungsi mendidik dan membina kebiasaan siswa di sekolah kearah berpola pikir dan berperilaku lebih baik. Karena dengan adanya sanksi pelanggaran dari keharusan atau pelarangan bagi siswa kita mestti yakin secara lambat maupun cepat mereka akan terbiasa melaksanakan disiplin sekolah dengan sadar dengan kepatuhan atau ketaatan yang tinggi tanpa perlu pengawasan yang ketat ataupun paksaan. Dari pembisaan patuh terhadap tata tertib yang dagariskan sekolah itulah yang tujuan dari proses usaha pembentukan karakter baik siswa akan berhasil terbentuk. Para siswa akan sadar melaksanakan kwajibannya sebagai peserta didik disekolahnya maupun dirumah atau dalam pergaulan dilingkungannya. Mereka akan berperilaku Religius, disiplin, tanngung jawab, jujur, giat belajar, berdaya saing tinggi, peduli linkungan, hormat pada guru, orang tua, rapi, ramah dan sopan serta menghargai sesama.

\section{Pembentukan Karakter Siswa Disekolah}

Sudah banyak dijelaskan diatas bahwa baik dan buruknya karakter individu maupun kelompok dengan mudah bisa dibedakan seseorang dengan orang lainnya/ sekelompok orang dengan kelompok orang lainnya dari cara berpikir dan berperilaku yang menjadi ciri khas setiap individu/kelompok tersebut dalam hidup mandiri atau bekerjasama dalam masyarakat.

Sekolah merupakan lembaga pendidikan yang diciptakan oleh masyarakat untuk menyediakan lingkungan belajar dan ruang belajar untuk belajar dan mengajar serta tempat menerima dan memberi pelajaran. Kegiatan pembelajaran diselenggarakan untuk membentuk watak/karakter, membangun 
pengetahuan, sikap dan kebiasaan-kebiasaan untuk meningkatkan mutu kehidupan peserta didik. Upaya pembentukan karakter bagi siswa sekolah menengah pertama perlu dilakukan secara terus menerus untuk meningkatkan karakter baiknya dalam rangka membentuk warga negara yang berkarakter lebih baik dan competence lebih tinggi dan tangguh kemampuannya karena karakter baik merupakan salah satu sikap fundamental pola pikir dan perilaku seseorang untuk mencapai keberhasilan hidup yang lebih baik. Maka sudah selayaknya sekolah mempersiapkan peserta didiknya berkarakter lebih baik yang menjujung tinggi budaya dan etika sebagai bekal hidup bermasyarakat, berbangsa dan bernegara di masa depannya.

Sekolah yang merupakan pusat pengembangan budaya yang adi luhung peningkatan kedisiplinan dan ketertiban di lingkungan sekolah memang sangatlah penting, karena hal ini sering kali terjadi pelanggaran kedisiplinan dan ketertiban yang dilakukan para siswa. Oleh sebab itu kedisiplinan dan ketertiban perlu kita atur dalam sebuah tatanan yang biasa kita sebut dengan tata tertib sekolah.

Adapun dibuatnya tata tertib tersebut memiliki dua tujuan yaitu tujuan khusus dan juga tujuan umum. Secara khusus memiliki tujuan supaya kepala sekolah bisa menciptakan suasana yang kondusif bagi semua warga sekolah, supaya para guru bisa melaksanakan belajar mengajar dengan optimal dan supaya tercipta kerja sama di antara para orang tua dengan sekolah dalam mengemban tugas pendidikan. Sedangkan tujuan secara umumnya yaitu agar terlaksananya kurikulum secara baik serta bisa menunjang peningkatan mutu pendidikan di dalam sekolah.

Sama halnya bagi pembentukan karakter seorang anak, memang butuh waktu dan komitmen dari orangtua dan sekolah atau guru (jika memprioritaskan hal ini) untuk mendidik anak menjadi pribadi yang berkarakter. Butuh upaya, waktu dan cinta dari lingkungan yang merupakan tempat dia bertumbuh, cinta disini jangan disalah artikan memanjakan. Jika kita taat dengan proses ini maka dampaknya bukan ke anak kita, kepada kitapun berdampak positif, paling tidak karakter sabar, toleransi, mampu memahami masalah dari sudut pandang yang berbeda, disiplin dan memiliki integritas (ucapan dan tindakan sama) terpancar di diri kita sebagai orangtua ataupun guru. Hebatnya, proses ini mengerjakan pekerjaan baik bagi orangtua, guru dan anak jika kita komitmen pada proses pembentukan karakter.

Bagaimna membentuk karakter siswa melalui disiplin tata tertib sekolah? Seperti contoh tata tertib di atas seakan hanya menyinggung apa-apa yang harus dilakukan atau tidak dilakukan oleh siswa semata. Apakah tata tertib itu bisa terlaksana dengan yang diharapkan? Tentu saja tidak. Program/aturan sekolah untuk mendungnya sangat diperlukan. Stake holder sangat penting peranananya, meskipun tidak perlu seperti polisi atau hakim dengan vonis yang menakutkan.

Suatu contoh di Sekolah Menengah Pertama Negeri 3 Tulungagung untuk mendorong tercapainya tertib kedatangan siwa disekolah (I.1. Semua Siswa harus hadir disekolah selambat-lambatnya 10 menit sebelum pelajaran dimulai.) sekolah mengadakan Progam 3.S (salam senyum sapa) yang diaplikasikan setiap pagi oleh kepala sekolah bersama staf dan guru BP menyambut kedatangan siswa disekolah dengan menyalaminya dan berbagai sambutan keramahan yang lain. Hasil dari pelaksanaan program 3.S ini peserta didik yang datang kesekolah terlambat menjadi jauh berkurang atau sekitar dibawah sepuluh anak dengan 
alasan keterlambatan yang sangat masuk akal/tidak dibuat-buat, berarti tingkat kedisiplinan kehadiran siswa di sekolah bisa dipantau untuk ditingkatkan. Selain itu program 3S ternyata berdampak pada kerapian dan kelengkapan pakaian anak meningkat baik. Siswa menjadi terbiasa saling beertegur sapa antar teman selevelnya atau terhadap senior/yuniornya, gurunya atau warga sekolah yang lain dengan tata krama/sopan santun yang berlaku dilingkungan sekolah. Program Salam Senyum Sapa bagi sekolah manfaat besar sekali, sekolah dengan mudah memantau kebisaan baik dan buruk dari perilaku dan pola pikir iandividu-individu peserta didik dengan mudah. Peserta didik menjadi merasa dihargai dan diperhatikan sehingga mereka merasa nyaman dan aman di sekolah.

Piket Kelas, piket kerja kelas yang beranggotakan rata-rata seperenan dari jumlah rombongan belajar dalam satu kelas siswa bertugas menkondisikan dalam/luar ruang kelas dalam keadaan bersih dan rapi, serta mempersiapkan alat bantu belajar mengajar untuk siap digunakan sebagai tempat proses pembelajaran. Kwajiban ini bertujuan supaya anak memiliki sikap gotong royong, peduli dan rasa bertanggung jawab terhadap sesam dan lingkungan sosial disekolahnya.

Selain itu masih ada program wajib/ peraturan pendukung yang dilaksanakan disekolah untuk membentuk karakter baik siswa yaitu: (1) Upacara bendera setiap hari Senin atau hari besar kenegaraan lainnya untuk menumbuhkan watak disiplin dan jiwa patriotism dalam berbangsa dan bernegara; (2) Hormat bendera, berdoa, salam keada guru setiap awal/jam pertama pembelajaran pagi hari dan jam terakir pembelajaran di siang hari untuk mengembangkan ketakwaan dalam beragama dan menghormati bendera negara serta menjujung tinggi harkat dan martabat bangsa; (3) Mengucapkan salam kepada guru yang datang diawal atau meninggalkan kelas selesai pembelajaran untuk membangun rasa hormat dan membiasakan bertegur sapa dengan santun pada guru atau warga sekolah lainnya; (4) Melaksanakan kegiatan Jumat bersih baik dalam atau luar lingkungan kelas/sekolah yang berupa kerja social bersama siswa, guru dan seluruh stake holder sekolah dalam rangka mencapai sekolah adi wiyata untuk meningkatkan rasa peduli, cinta dan rasa tanggung jawabnya terhadap lingkungan sekolah tempat belajarnya.

\section{KESIMPULAN}

Dampak positif yang muncul dengan adanya tata tertib sekolah akan membuat siswa menjadi patuh pada peraturan sekolah atau guru, introspeksi dan berjanji tidak akan melanggar peraturan lagi, menjaga ketertiban sekolah, dan membantu mendisiplinkan siswa. Konteks inilah yang akan membuat peserta didik bertutur sapa secara sopan, peduli antar sesama, meminimalisir adanya sifat acuh pada peringatan sekolah atau guru, selalu mengulang kesalahan yang sama, tidak mentaati peraturan sekolah, mempropokasi teman-temannya untuk melanggar peraturan sekolah, cenderung bersikap kearah kriminalitas, dendam kepada guru dan membentuk geng dan lain sebagainya.Tata tertib sekolah dan berbagai program pendukung operasionalnya di Sekolah Menengah Negeri 3 Tulungagung terbukti mampu meningkatkatkan disiplin baik dalam kehadiran di sekolah, berpakaian, berperilaku, rasa tanggung jawab terhadap kwajibannya, lebih rajin belajar yang menggambarkan ciri-ciri baik dari seorang peserta didik dan mengurangi kegiatan negative siswa. 


\section{SARAN}

Program meningkatkan disiplin pelaksanaan tata tertib sekolah dengan tujuan membentuk dan mengembangkan karakter baik peserta sangat perlu untukdi laksanakan di setiap sekolah. Dengan demikian karakter baik peserta didik bisa dikembangkan di lingkungan sekolah.

\section{DAFTAR RUJUKAN}

Mas'udi. 2000. Pengertian Disiplin Belajar Siswa. Yogyakarta: PT Tiga Serangkai.

Hurlock, E. B. 1990. Developmental psychology: a lifespan approach. Boston: McGraw-Hill.

Suradisastra, Djodjo. 1991. Pendidikan IPS I. Jakarta: Depdikbud.

Suratman, 1999. Pembinaan Mental, Fisik dan Disiplin. Jakarta: LAN.

Suyanto. 2017. Pengembangan Pendidikan Karakter. Direktorat Pembinaan Guru Pendidikan Menengah, Direktorat Jenderal Guru dan Tenaga Kependidikan. Jakarta: Kemdikbud.

Undang-undang Republik Indonesia Nomor 3 Tahun 2005 tentang Sistem Keolahragaan Nasional. 2007.

Westra, Pariarta. 1981. Ensiklopedi Administrasi. Jakarta: Gunung Agung

Widodo D.S. 1984. Administrasi Personalia dan Ketenagakerjaan. Yogyakarta: FISIPOL UGM. 